PROBLEMS

OF EDUCATION IN THE $21^{\text {st }}$ CENTURY Vol. 78 , No. 6, 2020

884

\title{
DISTANCE EDUCATION DURING COVID-19: THE PERSPECTIVE OF SLOVAK TEACHERS
}

\author{
Eva Ballová Mikušková, Marcela Verešová \\ Constantine the Philosopher University in Nitra, Slovakia \\ E-mail: ebmikuskova@ukf.sk, mveresova@ukf.sk
}

\begin{abstract}
As the new coronavirus SARS-CoV-2 (causing COVID-19) has begun to spread around the world, education has taken the form of distance education from one day to the next. To this day, little is known about distance education during the pandemic period from teachers' point of view, so the study focused on perception and management of distance education in primary school (primary and lower secondary education) and upper-secondary school (upper secondary education) teachers; and the main aim was to explore the connection between teaching experience, personality traits, and emotions of teachers and their perception and management of distance education during the coronavirus pandemic. The research sample consisted of 379 teachers $(89.7 \%$ women) aged $23-70$ years $(M=44.91 ; S D=10.38)$. They completed the questionnaire which consisted of: demographic questions, questions related to perception and management of distance education, the Positive and Negative Affect Schedule and the Big Five Inventory 2. During the pandemic period, the negative emotions of teachers increased while positive emotions decreased; distance education was closely related to emotions (and changes in emotions) and personality; moreover, teachers reported willingness to implement partial changes into their teaching after the pandemic period.
\end{abstract}

Keywords: distance education, personality traits, positive emotions, negative emotions

\section{Introduction}

As coronavirus SARS-CoV-2 (causing COVID-19) has begun to spread around the world, many countries took various measures and recommendations in a very short time. One of the key measures to prevent the spread of COVID-19 and slow down transmission was school closures - from kindergarten to universities. Slovakia was one of the countries with the fastest measures and responses to the new coronavirus pandemic. Based on the official statement of the Ministry of Education, Science, Research and Sport of the Slovak Republic, all schools in the country were closed (hereinafter the Ministry of Education) from March 16, 2020 (some schools were closed several days earlier, as the result of the prompt decision made by their founders) and face to face education was transformed into distance education. From March 26, 2020, the specific portal for official communication during the state of emergency was created in cooperation with several non-governmental organizations and the Ministry of Education. They provided an overview of the possibilities of distance education, recommendations, and guidelines for schools, teachers, professionals, and parents. Official guidelines regarding the content and organization of education for schools from the Ministry of Education did not exist until April 28, 2020. So, for six weeks, teachers had to organize distance teaching on their own. 


\section{Research Problem}

PROBLEMS

OF EDUCATION

IN THE $21^{\text {st }}$ CENTURY

Vol. 78 , No. 6, 2020

885

In general, education has taken the distance form from one day to the next. Although distance education was used to some extent also before, none of the teachers were fully prepared for such a situation, neither materially, nor didactically, or in terms of the content. To this day, little is known about distance education during the pandemic period from teachers' point of view (in this study, the term 'during the pandemic' reflects the time of school closures mandated by the government).

Shohel (2012) saw the barrier of distance education in the lack of teachers' motivation for such form of education and the poverty of the university training oriented on distance education. For primary schools (primary and lower-secondary education) should be the problem also in the cooperation of teachers with parents (online coordinated by teachers) - for the teacher, the parent becomes a necessary mediator of the student's learning process. According to the InterAgency Network for Emergency Education (INEE, 2020), parents (or other caretakers) may consider their role in education completely independent on the role of teachers which result in the lack of cooperation with teachers. Another problem lies in the low skills of parents in using modern technologies or systems for distance education. Anyway, distance education during a pandemic places significant demands on the whole education system, the most on teachers: such a situation makes it difficult for teachers to work effectively with students (Shohel \& Banks, 2010; Shohel, 2012). On the other hand, compared to frontal or conventional education, distance learning has the potential to be more innovative, efficient and effective in cooperation with students and their results (Danaher \& Umar, 2010; Latch \& Jung, 2009).

In Slovakia, several surveys tried to measure how distance education was perceived by parents and students (some of them were published in newspapers and were products of poll agencies, some of the data collection prepared by universities or Slovak Academy of Sciences have not been published yet), but none of them has provided reliable answers to questions such as how the teachers arranged the education, what possibilities they had in order to provide effective distance education (did they have school devices or did they use private ones? did they pay for internet connection they needed themselves?), the amount of time spent on teaching and preparing (voices are calling for a reduction in teachers' salaries because of putative lower job effort during home office); and what personality traits or characteristic could potentially improve management of distance education.

\section{Research Focus}

The research focused on experience, perception and management of distance education. One can expect that more experienced teachers are better in general, but the evidence is not clear. On one hand, Podolsky et al. (2019) found out that teaching experience positively relates to students' achievement and that less experienced teachers can learn from those who are more experienced. On the other hand, Irvine (2019) in an extensive literature review did not find enough evidence for the positive effect of experience on teachers'effectiveness. Moreover, longer teaching experience contributes to lower positive affect among teachers (Fernández-Berrocal et al., 2017) which is related to less effective teaching (Frenzel et al., 2016; Makhwathana et al. 2017). Moreover, Shohel (2012) drew attention to the basic predictors of effective work in the implementation of distance education - flexibility and adaptability of teachers in the qualified mastery of new information technologies so that teaching is quality and attractive for students. Paradoxically, young and less experienced teachers are more likely to be more effective; more experienced teachers with fewer skills in the use of modern technologies may perceive distance learning as threatening because they may fail in the conversion of teaching material to the digital form, in evaluating students' knowledge or may lack the interaction 
Eva BALLOVÁ MIKUŠKOVÁ, Marcela VEREŠOVÁ. Distance education during Covid-19: The perspective of Slovak teachers

PROBLEMS

OF EDUCATION

IN THE $21^{\text {st }}$ CENTURY Vol. 78, No. 6,2020

886

between teachers and students (Tao \& Yeh, 2008). The ambiguous findings in combination with the lack of systematic research on distance education led to raise the question regarding the relation between experience and the perception and management of distance education.

Teaching is considered to be an emotional profession associated with a high level of stress (Fernández-Berrocal et al., 2017), emotional exhaustion (Näring et al., 2006; Yoo \& Carter, 2017), and intense effort from teachers to regulate experienced emotions (Grandey, 2003). Emotions are viewed as important determinants of teachers' burnout risk (Frenzel et al., 2009), well-being (Diener \& Chan, 2011; Näring et al., 2011), and work performance (Frenzel et al., 2009). Moreover, teachers' emotions are associated with teacher quality and relationship with students (for review of studies, see Frenzel et al., 2016): positive emotions are related to effective teaching (Frenzel et al., 2016; Makhwathana et al., 2017) and negative emotions frequently result in loss of control and negative behavior (Makhwathana et al., 2017). Teacher's performance may suffer owing to high levels of stress and this may impact on student learning (during distance education, too; Ferguson et al., 2017), and school reform (in our research study the term reform is associated with transformation of education due to the coronavirus pandemic) revealed potentially high levels of emotional stress triggered by externally mandated performance criteria (Yoo \& Carter, 2017). Emotion and emotional distress, therefore, cannot be considered separate from the learning environment.

The pandemic brings with it a higher level of anxiety and feeling of hopelessness (Cypryańska \& Nezlek, 2020) and teachers in general experience increased anxiety and helplessness in the same way as people from other professional backgrounds. Since the reform (or pandemic situation from our point of view) is always a request for a change in teaching practices, teachers need to learn new things (e.g. Yoo \& Carter, 2017). The study conducted during the pandemic situation (Burstein, 2020) found that the number of teachers who feel successful dropped from $96 \%$ before the switch to distance education to $73 \%$ during distance education; more than 5,000 educators co-administered by the Yale Center for Emotional Intelligence and the Collaborative for Academic, Social, and Emotional Learning (CASEL) mentioned the following frequently-felt emotional states during distance education in pandemic situation: anxious, fearful, worried, overwhelmed, and sad. School leaders felt similarly. The educational situation during the spread of COVID-19 highlighted teachers' professional skills and competences and significantly affected teachers' emotions. Research regarding the impact of emotion and cognition provides compelling evidence that the relation between emotion, education and learning should be examined further (Cleveland-Innes \& Campbell, 2012). So, the question was how teachers' emotions (and changes in emotions; both the prevailing emotions before the pandemic and current emotions during the coronavirus pandemic were measured) were related to the perception and management of distance education.

Finally, the teacher's personality is an important and complex variable in the educational process (Göncz, 2017) and is directly associated with teachers' work engagement and job satisfaction (Kokkinos, 2007; Perera et al., 2018), as well as performance and retention outcomes (Klassen \& Tze, 2014; Rockoff et al., 2011). Liao and Lee (2009) revealed that engagement in the workplace was positively correlated with nearly all the Big five dimensions, except for neuroticism, which presented a negative relation. Göncz (2017) notes that pronounced neuroticism (which encompasses negative emotions, pessimism, low tolerance for frustration, impulsiveness and so forth) is not a desirable trait for teachers to have in most pedagogical situations or in interactions with students (including distance learning). It is not very likely that teachers with high neuroticism are capable to build dynamic communicative relationships to their students, and many of them will need a great deal of time to improve their social skills. With regard to the other dimensions, it is assumed that they would be more pronounced in a good teacher than in the general population. Moderate extraversion is desirable as it is associated with friendliness, self-confidence and positive emotions. Efficient teachers should 
be open to novelty, curious and creative and have a well-developed vocabulary. Moreover, such teachers should be receptive to unconventional ideas and beliefs and accepting of different cultural backgrounds and the various feelings and behaviors of their students. A high degree of agreeableness is also necessary for successful pedagogic work. A good teacher should be cooperative, willing to compromise, mild-mannered and benevolent with faith in mankind. In addition, a good teacher must also have a reasonable level of conscientiousness so that characteristics such as competence, order, sense of duty, planning, self-discipline, impulse control and dedication can emerge in his / her work.

A lot of research has been carried out in this area, so Kim et al. (2019) conducted a meta-analysis in order to examine the association between each of the Big Five personality traits and teachers' effectiveness and burnout. They analyzed 25 studies and found out that extraversion, conscientiousness, negative emotionality, and open-mindedness of teachers could account for students' educational experiences and outcomes, while extraversion was slightly more significantly associated with teacher effectiveness comparing to conscientiousness which was considered to be a strong predictor of job performance in general (Barrick \& Mount, 1993). Also a meta-analysis conducted by Judges et al. (2002) revealed a positive correlation between job satisfaction and extraversion, agreeableness, conscientiousness, and a negative correlation with neuroticism, and they also emphasized a significant correlation between job satisfaction and extraversion and neuroticism, regardless of profession. In the present study, the relation between specific factors of personality and perception and management of distance education (in both positive and negative ways) was examined.

\section{Research Aim and Research Questions}

The main aim of the research was (a) to describe perception and management of distance education of primary school and upper-secondary school teachers and its comparison to situation before the pandemic period, and (b) to explore the connection between teaching experience, personality traits, and emotions on the one hand and perception and management of distance education during new coronavirus pandemic on the other hand. In Slovakia, the primary schools cover primary (grade 1-4) and lower secondary education (grade 5-9), and upper-secondary schools cover upper-secondary education. Primary schools and upper-secondary schools have their specific processes and needs, therefore, in present study, primary school teachers and upper-secondary school teachers were first compared in their responses. Following research questions were postulated for primary and upper-secondary school teachers:

1. What was the relation between experience and the perception and management of distance education?

2. How teachers' emotions (and changes in emotions) relate to the perception and management of distance education?

3. What was the relation between specific factors of personality and perception and management of distance education?

\section{Research Methodology}

\section{General Background}

The exploratory study was conducted to examine teaching experience, personality traits, and emotions and their relation to perception and management of distance education during the pandemic in primary and upper-secondary teachers.

All primary and upper-secondary schools in Slovakia-a total of 2,074 primary schools and 673 upper-secondary schools-were asked to participate in the research via email (available 
Eva BALLOVÁ MIKUŠKOVÁ, Marcela VEREŠOVÁ. Distance education during Covid-19: The perspective of Slovak teachers

PROBLEMS

OF EDUCATION

IN THE $21^{\text {st }}$ CENTURY Vol. 78, No. 6,2020

888

on the portal of Slovak Centre of Scientific and Technical Information); all principals were asked to send call for participation to all teachers in their school. The data were collected in April 2020 through on-line google form (before the Ministry of Education, Science, Research and Sport of the Slovak Republic has published uniform guidelines for teachers on April 28, 2020).

\section{Sample}

The sample size was calculated using an alpha of .05 and a confidence interval 95\%; yielding a sample of $383+5 \%$. Data collection was to be terminated after reaching the desired number (400). A total of 412 teachers responded to the call and opened on-line form; 11 of them did not agree with participation in the research, 2 of them did not qualify (they were not teachers), 1 person filled in the questions schematically, and 19 did not finish all questionnaires. Finally, 379 teachers $(89.7 \%$ women $)$ aged $23-70$ years $(M=44.91 ; S D=10.38)$ were included in the analyses; $79.7 \%$ primary school teachers and $20.3 \%$ upper-secondary school teachers. The teachers varied in their teaching experience from 1 to 45 years and they teach at average 3.23 subjects (Table 1). On average, teachers live with other 3.20 members $(S D=1.50)$ in a household, $40.6 \%$ of them were living with at least one child (and $65.84 \%$ of home childcare was provided by teachers).

Participation was voluntary and anonymous. The participants did not receive any reward for their participation. The study was carried out following ethical principles introduced by the American Psychological Association. The data were collected just for the purpose of the research study and were anonymized so they could not be traced.

\section{Instrument and Procedures}

After signing a consent form, all teachers completed the questionnaire which included demographic questions, questions about information and communications technology (ICT) use, questions about perception and management of distance teaching, statements regarding subjective and objective satisfaction with their teaching. Finally, teachers rated their emotions and personality traits.

Demographic questions. All teachers answered questions about their age, sex, number of people in the household (mainly school children), questions about years of teaching experience [experience], type of school they work at (primary school - 1-4 grade, 5-9 grade; uppersecondary school - vocational, general), number of subjects they teach, and the amount of free time.

Information and communications technology (ICT) use. The teachers answered questions about their ownership and use of phone, smartphone, tablet, computer, and internet connection for teaching purposes on a 4-point scale (I do not own-I own, but do not use-I own and use my personal-I have and use the business one).

Teaching management. All participants rated their use of different communication channels in terms of its frequency (phone, mail, EduPage - cloud-based school management system, Zoom, Webex, Moodle, Jitsi Meet, Skype, Microsoft Teams, Google Classroom, Messenger, Facebook, WhatsApp, Viber, Hangouts, others) before and during the pandemic period on a 7 -point scale $(0=\mathrm{I}$ do not use; $7=4$ and more hours a day). The total number of used channels was computed for the time before [ $n$ of com_channels-before] and during [ $n$ of com channels-during] the pandemic period. The frequency of their use was recoded into hours per day to estimate the number of hours per day spent on distance teaching and communication with students. The mean of estimated hours before [hours of DT-before] and during the pandemic period [hours of DT-during] was computed. Teachers estimated also the number of hours per 
day they spent on preparation, again before and during the pandemic period $(0=$ less than one hour; $5=5$ and more hours). The mean of estimated hours before [hours of preparation-before] and during [hours of preparation-during] the coronavirus pandemic was computed. Next, the teachers rated the use of eight forms of teaching (e.g. 'I send assignments to students, they work at home alone.'; 'We repeat the topics already taught before the pandemic period.'; 'I assess students verbally.') on a 3-point scale (I do not use-I use sometimes-I use). The mean for each form of teaching was computed; the higher score indicated a higher frequency of use.

Satisfaction. The teachers assessed the level of satisfaction with their own system of distance education ( 2 items), with institutional support from headmasters, founders, and ministry (5 items), and how satisfied with their teaching were students, parents and school leadership teams ( 6 items) on a 6 -point scale $(1=$ completely dissatisfied; $6=$ completely satisfied). The mean was computed for subjective satisfaction with the individually developed system of work [subjective satisfaction], for satisfaction with institutional support [satisfaction with institution support], and feedback [feedback]; the higher score indicated higher satisfaction and more positive feedback.

Expectations for the future. The teachers expressed the attitudes toward the teaching style they would like to implement into their work after the pandemic period. They could choose from five options: from 'Finally, teaching will return to the old ways and I will continue using my teaching style.' to 'I will not return to my old teaching style.' The mean was computed for expectations [expectation]; the higher score indicated expecting more changes in teaching.

Feelings of anxiety and lack of control concerning the coronavirus pandemic. Participants indicated their agreement with 6 statements reflecting feelings of anxiety and the 6 statements reflecting the lack of control over their lives or health as the result of the COVID-19 pandemic (Šrol et al., 2020) on a 6-point scale ( $1=$ completely disagree; $6=$ completely agree). Average ratings for the feelings of anxiety [anxiety-COVID] and the lack of control [lack of controlCOVID] concerning the new coronavirus were computed. The higher score indicated more intense feelings of anxiety and the lack of control.

Perceived risk of coronavirus. Participants rated 3 statements regarding the perceived infectiousness, severity, and overall dangerousness of the new coronavirus (Šrol et al., 2020) on a 6 -point scale $(1=$ completely disagree; $6=$ completely agree). The average score for the perceived risk of the coronavirus [perceived risk-COVID] was computed; the higher score indicated higher perceived risk of new coronavirus.

Positive and negative emotions. To measure positive and negative emotions the Positive and negative affect schedule (PANAS; Watson \& Clark, 1988) was administered. First, all participants were asked to rate their prevailing mood and emotions before the coronavirus pandemic; subsequently to measure changes in their emotions they were asked to rate their current mood and emotions (during the pandemic period), both on a 6-point scale (1=not at all; $6=$ very often). The means for current positive [positive affect] and negative [negative affect] emotions were computed; the higher score indicated stronger positive/negative emotions. The difference between current emotions and emotions before the pandemic period as a measure of the change in emotions [positive affect-changes; negative affect-changes] was computed; the higher positive/negative score indicated increased/decreased current emotions.

Personality traits. To measure personality traits, the Big Five Inventory (BFI-2; Slovak adaptation by Halama et al., 2020) was used. The teachers assessed 60 statements on a 6-point scale ( $1=\mathrm{I}$ do not agree at all; $6=\mathrm{I}$ totally agree) in order to measure their extraversion $[\mathrm{E}]$, agreeableness $[\mathrm{A}]$, conscientiousness $[\mathrm{C}]$, negative emotionality $[\mathrm{N}]$, and open-mindedness $[\mathrm{O}]$. The mean for 5 domains was computed; the higher score indicated the stronger particular personality trait. 
Eva BALLOVÁ MIKUŠKOVÁ, Marcela VEREŠOVÁ. Distance education during Covid-19: The perspective of Slovak teachers

PROBLEMS

OF EDUCATION

IN THE $21^{\text {st }}$ CENTURY

Vol. 78, No. 6,2020

890

\section{Data Analysis}

To examine potential differences between primary school and upper-secondary school teachers in all measured variables, the independent sample $t$-test was used. The upper-secondary correlation analysis was conducted to examine correlation between experience and the perception and management of distance education, between emotions and the perception and management of distance education, and between specific factors of personality and perception and management of distance education.

\section{Research Results}

First, teachers from primary schools and upper-secondary schools have been compared in all variables. There were significant differences in the number of subjects they teach, in using tablets for distance education, in the number of communication channels they used, in the amount of time spent on teaching through these channels, and in used ways of distance teaching (Appendix A). Primary school teachers taught at average 4.79 subjects, while other teachers taught approximately 2.07-3.14 disciplines, moreover primary school teachers also spent on distance education at average 4.14 hours per day in comparison to upper-secondary school teachers $(M=6.47$ hours per day).

Descriptive statistics of all measured variables are presented in Table 1. Primary school teachers reported 19.56 years $(S D=10.86)$ and upper-secondary school teachers reported 17.10 years $(S D=11.14)$ of teaching experience and they taught approximately 3 subjects. In general, teachers most frequently used to send assignments to their students (students work at home alone) and checked students' tasks completion. The teachers also introduced new topics. Primary school teachers assessed their students more often verbally; upper-secondary school teachers used significantly more often marks to assess specific knowledge of students.

The subjective satisfaction and satisfaction with institutional support was at a medium level, and teachers assessed feedback from students, parents, and headmasters/school leadership teams as positive (about 5 points out of 6). Teachers' expectations about their system of teaching after the pandemic period were below the midpoint which corresponds with the expectation that they would just partly return to their teaching style and partly implement some experience with distance education during the pandemic period (only $5.6 \%$ of primary school teachers and $3.9 \%$ of upper-secondary school teachers expressed a willingness to change their teaching style. On the contrary, $8.9 \%$ of primary school teachers and $11.7 \%$ of upper-secondary school teachers reported using again traditional teaching style after the pandemic period). 
Table 1

Descriptive Statistics of Measured Variables

\begin{tabular}{|c|c|c|c|c|c|c|c|c|}
\hline & \multicolumn{2}{|c|}{$\begin{array}{l}\text { Internal } \\
\text { consistency }\end{array}$} & \multicolumn{2}{|l|}{$M(S D)$} & \multicolumn{2}{|l|}{ Md } & \multicolumn{2}{|l|}{ Mo } \\
\hline & $P$ & U-S & $P$ & U-S & $P$ & U-S & $P$ & U-S \\
\hline \multicolumn{9}{|l|}{ Demography } \\
\hline Age & - & - & $\begin{array}{l}45.14 \\
(9.97)\end{array}$ & $44.03(11.86)$ & 45 & 44 & $43^{b}$ & $42^{b}$ \\
\hline Persons in household & - & - & $3.27(1.45)$ & $2.91(1.66)$ & 3 & 3 & 4 & 2 \\
\hline Children in household & - & - & $0.71(0.91)$ & $0.38(0.67)$ & 0 & 0 & 0 & 0 \\
\hline Number of subjects & - & - & $3.35(2.06)$ & $2.77(1.86)$ & 3 & 2 & 2 & 2 \\
\hline Experience & - & - & $\begin{array}{l}19.56 \\
(10.86)\end{array}$ & $17.10(11.14)$ & 20 & 17 & 20 & $3^{b}$ \\
\hline \multicolumn{9}{|l|}{ Forms of distance teaching } \\
\hline $\begin{array}{l}\text { 1. Sending assignments to students, they } \\
\text { work at home alone }\end{array}$ & - & - & $1.70(0.52)$ & $1.81(0.43)$ & 2 & 2 & 2 & 2 \\
\hline 2. Checking students' tasks completion & - & - & $1.85(0.41)$ & $1.92(0.27)$ & 2 & 2 & 2 & 2 \\
\hline $\begin{array}{l}\text { 3. Repeating the topics that were covered } \\
\text { before the pandemic. }\end{array}$ & - & - & $1.40(0.64)$ & $1.30(0.65)$ & 1 & 1 & 2 & 1 \\
\hline 4. Covering new topics & - & - & $1.74(0.52)$ & $1.77(0.51)$ & 2 & 2 & 2 & 2 \\
\hline 5. Verbal assessment of studentsi & - & - & $1.79(0.45)$ & $1.34(0.72)$ & 2 & 1 & 2 & 2 \\
\hline 6. Assessment of students using marksiii & - & - & $0.50(0.69)$ & $1.48(0.68)$ & 0 & 2 & 0 & 2 \\
\hline $\begin{array}{l}\text { 7. Verifying students' knowledge through } \\
\text { oral examination }\end{array}$ & - & - & $0.46(0.70)$ & $0.39(0.69)$ & 0 & 0 & 0 & 0 \\
\hline 8. Verifying students' knowledge with tests ${ }^{\text {iv }}$ & - & - & $0.63(0.69)$ & $0.86(0.77)$ & 1 & 1 & 0 & 1 \\
\hline \multicolumn{9}{|l|}{ Perception of DT } \\
\hline Subjective satisfaction & - & - & $3.89(0.93)$ & $3.79(0.82)$ & 4 & 3.5 & 4 & 3.5 \\
\hline Satisfaction with institutional support & .877 & .871 & $3.93(1.27)$ & $4.22(1.19)$ & 4 & 4.2 & 6 & $4.2^{b}$ \\
\hline Feedback $^{v}$ & .720 & 690 & $4.96(0.74)$ & $4.78(0.65 n ̌$ & 5 & 4.8 & 5.5 & 5.5 \\
\hline Expectation & - & - & $2.42(0.71)$ & $2.40(0.78)$ & 2 & 2 & 3 & 3 \\
\hline \multicolumn{9}{|l|}{ Emotions } \\
\hline Anxiety (COVID) & .644 & .504 & $3.29(0.77)$ & $3.35(0.70)$ & 3.2 & 3.3 & 3 & 3.3 \\
\hline Lack of control (COVID) & .609 & .536 & $3.32(0.68)$ & $3.29(0.63)$ & 3.2 & 3.3 & 3 & 3 \\
\hline Perceived risk (COVID) & .899 & .851 & $4.64(1.08)$ & $4.88(0.90)$ & 4.7 & 5 & 6 & 5 \\
\hline Positive affect & .896 & .906 & $3.32(0.70)$ & $3.56(0.70)$ & 3.3 & 3.6 & 2.9 & $3.4^{b}$ \\
\hline Negative affect & .892 & .904 & $1.98(0.67)$ & $1.97(0.73)$ & 1.9 & 1.8 & $1^{\mathrm{b}}$ & $1.5^{b}$ \\
\hline Positive affect - changes & - & - & $-0.33(0.53)$ & $-0.29(0.41)$ & -0.2 & -0.2 & 0 & 0 \\
\hline Negative affect - changes & - & - & $0.31(0.59)$ & $0.31(0.52)$ & 0.2 & 0.2 & 0 & 0 \\
\hline \multicolumn{9}{|l|}{ Personality } \\
\hline Extraversion & .766 & .821 & $4.14(0.66)$ & $4.22(0.75)$ & 4.1 & 4.3 & 3.8 & 3.8 \\
\hline Agreeableness & .826 & .816 & $4.93(0.63)$ & $5.08(0.53)$ & 5 & 5.2 & 4.8 & 5.2 \\
\hline Conscientiousness & .867 & .878 & $4.79(0.74)$ & $4.81(0.75)$ & 4.8 & 5 & $4.8^{b}$ & 5.1 \\
\hline Negative emotionality & .844 & .866 & $2.82(0.75)$ & $2.78(0.80)$ & 2.8 & 2.8 & 2.9 & $2.5^{\mathrm{b}}$ \\
\hline Open-mindedness & .803 & .818 & $4.54(0.71)$ & $4.77(0.72)$ & 4.5 & 4.8 & 4.7 & 5.6 \\
\hline
\end{tabular}

Note: $N_{\text {primary }}=302 ; N_{\text {upeer-secondary }}=77$; internal consistency was measured by omega; P - primary school teachers, U-S upper-secondary school teachers, ${ }^{b}$ Multiple modes exist - the smallest value is shown; significant differences between primary and upper-secondary school teachers: ${ }^{\prime}(t=2.238 ; p=.026)$; ${ }^{i}(t=6.864 ; p<.001)$, iii $(t=11.256 ; p<.001),{ }^{i}(t=$ $2.495 ; p=.013),{ }^{v}(t=2.001 ; p=.046)$ 
Eva BALLOVÁ MIKUŠKOVÁ, Marcela VEREŠOVÁ. Distance education during Covid-19: The perspective of Slovak teachers

PROBLEMS

OF EDUCATION

IN THE $21^{\text {st }}$ CENTURY

Vol. 78, No. 6,2020

892

To conduct distance education, most of the teachers used their own devices (smartphones, computers, tablets) and all teachers used private internet connection without refunding these fees by the employer (Table 2); and only about a quarter of teachers used staff computers.

Table 2

ICT Ownership and Use (\%)

\begin{tabular}{|c|c|c|c|c|c|c|c|c|c|c|}
\hline & \multicolumn{2}{|c|}{ Phone } & \multicolumn{2}{|c|}{ Smartphone } & \multicolumn{2}{|l|}{ PC } & \multicolumn{2}{|c|}{ Tablet } & \multicolumn{2}{|c|}{ Internet } \\
\hline & $\mathrm{P}$ & U-S & $\mathrm{P}$ & U-S & $\mathrm{P}$ & U-S & $P$ & U-S & $\mathrm{P}$ & U-S \\
\hline I do not own & 56.3 & 57.1 & 12.3 & 10.4 & 0.7 & 0.0 & 49.7 & 37.7 & 0.0 & 0.0 \\
\hline I own, but don't use & 11.3 & 18.2 & 7.9 & 13 & 0.0 & 0.0 & 27.2 & 27.3 & 0.0 & 0.0 \\
\hline $\begin{array}{l}\text { Town and use private } \\
\text { one }\end{array}$ & 31.5 & 23.4 & 77.5 & 74 & 74.2 & 76.6 & 18.2 & 24.7 & 100 & 100 \\
\hline I use school one & 1 & 1.3 & 2.3 & 2.6 & 25.2 & 23.4 & 5 & 10.4 & 0.0 & 0.0 \\
\hline
\end{tabular}

Note: $\mathrm{P}$ - primary school teachers, U-S - upper-secondary school teachers

\section{Changes in Teaching Management}

All aspects of teaching management changed during the pandemic period compared to the situation before the pandemic period (Table 3); teachers used more communication channels (more applications and internet portals), they spent more hours on distance education and more time on preparation (and have less free time; on the contrary, upper-secondary school teachers reported having as much free time as before the pandemic period). Increased negative and decreased positive emotions were identified in both samples during the pandemic period (Table $1)$.

Table 3

Differences between Teaching Management before and during Pandemic

\begin{tabular}{|c|c|c|c|c|c|c|c|c|}
\hline & \multicolumn{3}{|c|}{ Primary school } & \multicolumn{5}{|c|}{ Upper-secondary school } \\
\hline & $N$ & $M$ & $S D$ & & $N$ & $M$ & $S D$ & \\
\hline \multirow{2}{*}{$\begin{array}{l}\mathrm{N} \text { of com_channels - } \\
\text { before } \\
\mathrm{N} \text { of com_channels - } \\
\text { during }\end{array}$} & 302 & 3.00 & 1.70 & \multirow{2}{*}{$\begin{array}{l}t_{(301)}=14.581 ; \\
p<.001 \\
d=0.839\end{array}$} & & 3.69 & 1.28 & \multirow{2}{*}{$\begin{array}{l}t_{(76)}=6.310 \\
p<.001 \\
d=0.719\end{array}$} \\
\hline & 302 & 4.25 & 1.50 & & 77 & 4.47 & 1.35 & \\
\hline Hours of DT - before ${ }^{\mathrm{il}}$ & 302 & 1.71 & 2.36 & \multirow{2}{*}{$\begin{array}{l}t_{(301)}=17.999 ; \\
p<.001 \\
d=1.036\end{array}$} & 77 & 2.45 & 2.59 & \multirow{2}{*}{$\begin{array}{l}t_{(76)}=10.837 \\
p<.001 \\
d=1.235\end{array}$} \\
\hline Hours of DT- during iii & 302 & 4.88 & 3.43 & & 77 & 6.08 & 3.66 & \\
\hline $\begin{array}{l}\text { Hours of preparation- } \\
\text { before }\end{array}$ & 302 & 2.18 & 1.04 & \multirow{2}{*}{$\begin{array}{l}t_{(301)}=12.164 ; \\
p<.001 ; \\
d=0.700\end{array}$} & 77 & 2.23 & 1.22 & \multirow{2}{*}{$\begin{array}{l}t_{(76)}=6.068 \\
p<.001 \\
d=0.691\end{array}$} \\
\hline $\begin{array}{l}\text { Hours of preparation - } \\
\text { during }\end{array}$ & 302 & 3.01 & 1.22 & & 77 & 3.12 & 1.42 & \\
\hline $\begin{array}{l}\text { Hours of free time - } \\
\text { pefore }\end{array}$ & 302 & 2.55 & 1.49 & \multirow{2}{*}{$\begin{array}{l}t_{(301)}=3.281 \\
p=.001 \\
d=0.189\end{array}$} & 77 & 2.55 & 1.59 & \multirow{2}{*}{$\begin{array}{l}t_{(76)}=0.962 \\
p=.339 \\
d=0.110\end{array}$} \\
\hline $\begin{array}{l}\text { Hours of free time - } \\
\text { during }\end{array}$ & 302 & 2.32 & 1.53 & & 77 & 2.42 & 1.63 & \\
\hline
\end{tabular}

Note: , $d$-Cohen's d; significant differences between primary and upper-secondary school teachers: ${ }^{i}(t=3.334 ; p=$ $.001), \mathrm{i}(t=2.404 ; p=.017), \mathrm{ii}(t=2.703 ; p=.007)$ 
Teaching During the Pandemic Period, Teaching Experience,

First, correlation analysis between experience and the perception and management of distance education was conducted. In the group of primary school teachers, teaching experience related positively to the number of communication channels $(r=.160 ; p=.005)$ and negatively to the form of teaching labelled as 'introducing new topics' $(r=-.132 ; p=.022)$. In the group of upper-secondary school teachers, there was no correlation between teaching experience and the perception and management of distance education.

Next, whether emotions were related to the way teachers conducted and perceived distance education during the new coronavirus pandemic was examined. In the sample of primary school teachers (Table 4a), results showed that positive emotions correlated positively with satisfaction with institutional support, perceived feedback, expectations regarding the future teaching style, and the form of teaching labelled as 'verifying students' knowledge using tests'. Decreased positive emotions during the pandemic period related to the lower satisfaction with institutional support and more frequent use of 'repeating the topics that were already taught.

Negative emotions were related positively to the amount of time spent on distance teaching and the form 'repeating the topics that were already taught' and negatively to the perceived feedback and expectations regarding the future teaching style. Increased negative emotions were related to more time spent on distance education, to more frequent use of 'repeating the topics that were already taught', and less frequent use of 'sending assignments to students, they work alone'.

Specific emotions related to the COVID-19 were analyzed. COVID related anxiety as well as COVID related lack of control were negatively correlated with expectations regarding the future teaching style, and perceived risk of COVID-19 was positively correlated with the time teachers spent on preparing to each teaching day and the form labelled as 'verbal assessment of students'. 
Eva BALLOVÁ MIKUŠKOVÁ, Marcela VEREŠOVÁ. Distance education during Covid-19: The perspective of Slovak teachers

PROBLEMS

OF EDUCATION IN THE $21^{\text {st }}$ CENTURY Vol. 78, No. 6,2020

894
Table 4a

Correlations between Perception and Management of Teaching and Emotions - Primary School during the Pandemic

\begin{tabular}{|c|c|c|c|c|c|c|c|}
\hline & \multicolumn{2}{|c|}{ Emotions (PANAS) } & \multicolumn{2}{|c|}{$\begin{array}{l}\text { Changes in } \\
\text { emotions (PANAS) }\end{array}$} & \multicolumn{3}{|c|}{$\begin{array}{l}\text { Negative emotions related to } \\
\text { COVID-19 }\end{array}$} \\
\hline & Positive & Negative & Positive & Negative & Anxiety & $\begin{array}{l}\text { Lack of } \\
\text { control }\end{array}$ & $\begin{array}{l}\text { Perceived } \\
\text { risk }\end{array}$ \\
\hline \multicolumn{8}{|l|}{ Management of DT } \\
\hline $\mathrm{N}$ of com_channels & -.019 & .070 & -.082 & .031 & -.029 & -.003 & -.029 \\
\hline Hours of DT & .046 & $.125^{\star}$ & -.086 & .169 ** & .035 & .066 & .085 \\
\hline Hours of preparation & .102 & .073 & -.032 & .111 & .100 & .080 & $.146^{*}$ \\
\hline $\begin{array}{l}\text { 1. Sending assignments to } \\
\text { students, they work alone }\end{array}$ & .039 & -.048 & .046 & $-.120^{*}$ & .063 & -.026 & .011 \\
\hline $\begin{array}{l}\text { 2. Check students' tasks } \\
\text { completion }\end{array}$ & .028 & -.002 & -.055 & .042 & -.043 & -.032 & .031 \\
\hline $\begin{array}{l}\text { 3. Repeating the topics that } \\
\text { were covered }\end{array}$ & -.028 & $.139 *$ & $-.141^{*}$ & $.166^{* *}$ & .108 & -.021 & .036 \\
\hline 4. Covering new topics & .009 & -.050 & -.019 & -.064 & -.001 & -.022 & .066 \\
\hline $\begin{array}{l}\text { 5. Verbal assessment of } \\
\text { students }\end{array}$ & .074 & .069 & -.040 & .093 & -.005 & .008 & $.142^{*}$ \\
\hline $\begin{array}{l}\text { 6. Assessment of students } \\
\text { using marks }\end{array}$ & .009 & -.023 & -.074 & .023 & -.027 & -.060 & -.052 \\
\hline $\begin{array}{l}\text { 7. Verifying students' knowledge } \\
\text { through oral examination r }\end{array}$ & .023 & .030 & -.050 & .061 & -.031 & .005 & -.025 \\
\hline $\begin{array}{l}\text { 8. Verifying students' knowledge } \\
\text { with tests }\end{array}$ & $.157^{* *}$ & -.097 & .096 & -.083 & -.059 & .031 & -.080 \\
\hline \multicolumn{8}{|l|}{ Perception of DT } \\
\hline Subjective satisfaction & .054 & -.105 & .006 & .039 & -.015 & -.057 & -.058 \\
\hline $\begin{array}{l}\text { Satisfaction with institutional } \\
\text { support }\end{array}$ & $.167^{\star *}$ & -.100 & $.196^{* *}$ & -.108 & .049 & .107 & .065 \\
\hline Feedback & $.233^{* *}$ & $-.148^{*}$ & .083 & -.019 & -.032 & .002 & .086 \\
\hline Expectations & $.131^{*}$ & $-.155^{\star *}$ & .089 & -.111 & $-.197^{* *}$ & $-.147^{*}$ & -.094 \\
\hline
\end{tabular}

Note: ${ }^{*}$ correlation is significant at the .05 level (2-tailed); ${ }^{* *}$ correlation is significant at the .01 level (2-tailed)

In the sample of upper-secondary school teachers (Table $4 \mathrm{~b}$ ), positive emotions were related positively only to the time spent on distance education; decreased positive emotions during the pandemic period were related to more frequent use of 'verbal assessment of students'. Negative emotions were negatively correlated with satisfaction with institutional support; and increased negative emotions were correlated with lower subjective satisfaction.

COVID-19 related anxiety correlated positively with the form 'verbal assessment of students' and perceived risk of COVID-19 was positively correlated with the amount of time spent on preparing for each teaching day and the form labelled as 'assessment of students using marks'. 
Table 4b

Correlations between Perception and Management of Teaching and Emotions - Upper-

\begin{tabular}{|c|c|c|c|c|c|c|c|}
\hline & \multicolumn{2}{|c|}{ Emotions (PANAS) } & \multicolumn{2}{|c|}{$\begin{array}{l}\text { Changes in } \\
\text { emotions (PANAS) }\end{array}$} & \multicolumn{3}{|c|}{$\begin{array}{l}\text { Negative emotions related to } \\
\text { COVID-19 }\end{array}$} \\
\hline & Positive & Negative & Positive & Negative & Anxiety & $\begin{array}{l}\text { Lack of } \\
\text { control }\end{array}$ & $\begin{array}{l}\text { Perceived } \\
\text { risk }\end{array}$ \\
\hline \multicolumn{8}{|l|}{ Management of DT } \\
\hline $\mathrm{N}$ of com_channels-during & .161 & -.130 & -.037 & -.103 & .126 & .101 & .177 \\
\hline Hours of DT & $.270^{*}$ & -.048 & -.030 & .147 & .112 & -.009 & .179 \\
\hline Hours of preparation & .016 & .170 & .001 & .191 & .162 & -.140 & .169 \\
\hline $\begin{array}{l}\text { 1. Sending assignments to } \\
\text { students, they work alone }\end{array}$ & -.086 & .019 & .001 & -.047 & -.031 & .033 & -.142 \\
\hline $\begin{array}{l}\text { 2. Check students' tasks } \\
\text { completion }\end{array}$ & .145 & -.173 & .077 & -.193 & .066 & -.046 & -.040 \\
\hline $\begin{array}{l}\text { 3. Repeating the topics that } \\
\text { were covered }\end{array}$ & -.010 & .072 & -.014 & .029 & .117 & .197 & .123 \\
\hline 4. Covering new topics & -.147 & .034 & -.104 & .026 & -.067 & .036 & .110 \\
\hline $\begin{array}{l}\text { 5. Verbal assessment of } \\
\text { students }\end{array}$ & -.105 & .007 & $-.254^{*}$ & .135 & $.321^{* *}$ & .013 & .112 \\
\hline $\begin{array}{l}\text { 6. Assessment of students } \\
\text { using marks }\end{array}$ & .041 & .098 & -.108 & .095 & -.001 & .069 & $.248^{*}$ \\
\hline $\begin{array}{l}\text { 7. Verifying students' knowledge } \\
\text { through oral examination }\end{array}$ & .083 & -.018 & -108 & .117 & .111 & -.031 & .098 \\
\hline $\begin{array}{l}\text { 8. Verifying students' knowledge } \\
\text { with tests }\end{array}$ & .012 & -.015 & .111 & .038 & .138 & .140 & .051 \\
\hline \multicolumn{8}{|l|}{ Perception of DT } \\
\hline Subjective satisfaction & -.066 & -.143 & .109 & $-.252^{*}$ & -.012 & -.014 & .024 \\
\hline $\begin{array}{l}\text { Satisfaction with institutional } \\
\text { support }\end{array}$ & .163 & $-.248^{*}$ & -.049 & .134 & .139 & .061 & .057 \\
\hline Feedback & .196 & -.186 & -.177 & .088 & .171 & -.128 & .153 \\
\hline Expectations & -.150 & .021 & .080 & -.036 & .121 & -.009 & .033 \\
\hline
\end{tabular}

Note: ${ }^{*}$ correlation is significant at the .05 level (2-tailed); ${ }^{* *}$ correlation is significant at the .01 level (2-tailed)

Next, correlation between personality and the perception and management of distance education was examined. In the group of primary school teachers (Table 5a), all personality factors were positively related to the perceived feedback except for the negative emotionality which correlated negatively with all personality factors. Next, agreeableness related positively and negative emotionality negatively to satisfaction with institutional support. Finally, openmindedness related negatively to subjective satisfaction and positively to expectations regarding the future teaching style and recommended 'repeating the topics that were already taught'. 
Eva BALLOVÁ MIKUŠKOVÁ, Marcela VEREŠOVÁ. Distance education during Covid-19: The perspective of Slovak teachers

PROBLEMS

OF EDUCATION

IN THE $21^{\text {st }}$ CENTURY Vol. 78, No. 6,2020

896

Table 5a

Correlations between Perception and Management of Teaching and Personality -Primary School Teachers during the Pandemic

\begin{tabular}{|c|c|c|c|c|c|}
\hline & \multicolumn{5}{|c|}{ Personality traits } \\
\hline & Extraversion & Agreeableness & Conscientiousness & $\begin{array}{l}\text { Negative } \\
\text { emotionality }\end{array}$ & $\begin{array}{l}\text { Open- } \\
\text { mindedness }\end{array}$ \\
\hline \multicolumn{6}{|l|}{ Management of DT } \\
\hline $\mathrm{N}$ of com_channels-during & .018 & .047 & -.020 & .083 & .013 \\
\hline Hours of DT & .066 & .047 & .075 & .068 & .031 \\
\hline Hours of preparation & -.051 & .101 & .112 & .010 & .088 \\
\hline $\begin{array}{l}\text { 1. Sending assignments to } \\
\text { students, they work alone }\end{array}$ & .035 & -.035 & -.013 & .002 & .067 \\
\hline $\begin{array}{l}\text { 2. Check students' tasks } \\
\text { completion }\end{array}$ & .026 & -.010 & -.001 & .009 & .047 \\
\hline $\begin{array}{l}\text { 3. Repeating the topics that } \\
\text { were covered }\end{array}$ & .090 & .042 & .096 & -.029 & $.118^{*}$ \\
\hline 4. Covering new topics & -.035 & -.010 & .010 & .041 & -.029 \\
\hline $\begin{array}{l}\text { 5. Verbal assessment of } \\
\text { students }\end{array}$ & .041 & .068 & .041 & .019 & .097 \\
\hline $\begin{array}{l}\text { 6. Assessment of students } \\
\text { using marks }\end{array}$ & .018 & -.031 & .023 & -.017 & .008 \\
\hline $\begin{array}{l}\text { 7. Verifying students' } \\
\text { knowledge through oral } \\
\text { examination }\end{array}$ & .093 & .070 & .034 & -.017 & .097 \\
\hline $\begin{array}{l}\text { 8. Verifying students' } \\
\text { knowledge with tests }\end{array}$ & .099 & -.027 & .078 & -.100 & .012 \\
\hline \multicolumn{6}{|l|}{ Perception of DT } \\
\hline Subjective satisfaction & .003 & .045 & .104 & -.052 & $-.142^{*}$ \\
\hline $\begin{array}{l}\text { Satisfaction with institutional } \\
\text { support }\end{array}$ & .055 & $.141^{*}$ & .099 & $-.136^{*}$ & .098 \\
\hline Feedback & $.126^{*}$ & $.295^{\star \star}$ & $.179^{\star *}$ & $-.147^{*}$ & $.164^{* *}$ \\
\hline Expectations & .069 & .104 & .027 & -.098 & $.156^{* *}$ \\
\hline
\end{tabular}

In the group of upper-secondary school teachers (Table $5 b$ ), extraversion, agreeableness, and open-mindedness related positively (negative emotionality related negatively) to the amount of time spent on distance education. The extraversion and open-mindedness correlated positively with perceived feedback; positive correlations were identified also between satisfaction with institutional support and open-mindedness, 'checking students' tasks completion' and conscientiousness, and 'verifying students' knowledge through oral examination' and extraversion and open-mindedness. 
Table 5b

Correlations between Perception and Management of Teaching and Personality - UpperSecondary School Teachers during the Pandemic

\begin{tabular}{|c|c|c|c|c|c|}
\hline & \multicolumn{5}{|c|}{ Personality traits } \\
\hline & Extraversion & Agreeableness & Conscientiousness & $\begin{array}{l}\text { Negative } \\
\text { emotionality }\end{array}$ & $\begin{array}{l}\text { Open- } \\
\text { mindedness }\end{array}$ \\
\hline \multicolumn{6}{|l|}{ Management of DT } \\
\hline $\mathrm{N}$ of com_channels-during & .215 & .109 & -.223 & -.106 & .075 \\
\hline Hours of DT & $.343^{* *}$ & $.384^{* *}$ & .174 & $-.233^{*}$ & $.283^{*}$ \\
\hline Hours of preparation & -.046 & .036 & -.061 & -.123 & .001 \\
\hline $\begin{array}{l}\text { 1. Sending assignments to } \\
\text { students, they work alone }\end{array}$ & -.167 & -.058 & -.006 & -.038 & -.035 \\
\hline $\begin{array}{l}\text { 2. Check students' tasks } \\
\text { completion }\end{array}$ & .164 & .028 & $.248^{\star}$ & -.141 & -.042 \\
\hline $\begin{array}{l}\text { 3. Repeating the topics that } \\
\text { were covered }\end{array}$ & -.001 & .021 & .099 & -.051 & .110 \\
\hline 4. Covering new topics & -.121 & .060 & -.099 & .020 & .069 \\
\hline $\begin{array}{l}\text { 5. Verbal assessment of } \\
\text { students }\end{array}$ & .040 & .034 & .053 & .014 & -.026 \\
\hline $\begin{array}{l}\text { 6. Assessment of students } \\
\text { using marks }\end{array}$ & .028 & .062 & .088 & .117 & .029 \\
\hline $\begin{array}{l}\text { 7. Verifying students' } \\
\text { knowledge through oral } \\
\text { examination }\end{array}$ & $.295^{\star *}$ & .168 & .088 & -.048 & $.313^{\star *}$ \\
\hline $\begin{array}{l}\text { 8. Verifying students' } \\
\text { knowledge with tests }\end{array}$ & -.208 & .044 & .076 & -.106 & .034 \\
\hline \multicolumn{6}{|l|}{ Perception of DT } \\
\hline Subjective satisfaction & -.039 & -.089 & .041 & .033 & -.160 \\
\hline Satisfaction with instit_support & .199 & .080 & -.037 & -.206 & $.241^{*}$ \\
\hline Feedback & $.255^{\star}$ & .210 & .134 & -.222 & $.227^{*}$ \\
\hline Expectations & -.208 & -.101 & -.083 & .047 & -.145 \\
\hline
\end{tabular}

\section{Discussion}

The main aim of the research was to examine perception and management of distance education in primary and upper-secondary school teachers and to explore connection between teaching experience, personality traits, and emotions of teachers and their perception and management of distance education during the new coronavirus pandemic. First, it is important to know the conditions under which teachers provided the distance education. Present research showed that primary school teachers taught more subjects, mainly the teachers of 1-4 grades because they often teach all subjects in one group. They also used fewer types of communication channels and spent less time on distance education, nevertheless the number of hours spent on distance education was still higher than recommended by Ministry of Education regarding 
Eva BALLOVÁ MIKUŠKOVÁ, Marcela VEREŠOVÁ. Distance education during Covid-19: The perspective of Slovak teachers

PROBLEMS

OF EDUCATION

IN THE $21^{\text {st }}$ CENTURY Vol. 78, No. 6,2020

898

the number of hours spent on education (announced after data collection) is 5-8 hours per week for 1-4 grades and 10-15 hours per week for 5-9 grades. And finally, primary school teachers assessed students more verbally and less by using marks (and through tests)-which was in accordance with later ministry recommendations-and they also received more positive feedback from parents and students. The spontaneous switch to more independent mode of teaching (mainly in primary school teachers) could explain the reason they described the feedback from parents and students as more positive. Although most of the teachers used their private devices and all of them used their private internet, they were still working very hard and doing their job as well as they could; they spent about 5-6 hours per day on distance education and another 3 hours on preparation. Of course, the amount of time devoted to the distance education was significantly higher than before the pandemic period when the education was conducted face to face. On the other hand, during the pandemic period teachers needed more time (at least one hour more) to plan and prepare activities for the next day, to check all tasks performed by students, and to send them feedbacks. To be in contact with students, teachers used different communication channels (primary school teachers used most often EduPage, e-mails, and Facebook groups and Messenger, upper-secondary school teachers used most frequently EduPage, e-mails, and Zoom; Appendix A) mainly for sending assignments and feedbacks to students and introducing new topics. Although the current recommendation of the Ministry of Education was to repeat the topics that were already taught before the pandemic period (during the data collection there were not any official recommendations), during the first weeks most of the teachers managed teaching in their own way and continued with new topics. The possible explanation is that at the beginning of the pandemic period, teachers did not know anything about the sanctions for noncompliance with the state educational programs, so they decided to follow the school curriculum.

In these conditions, experience, emotions, and personality were examined in relation to the perception and management of distance education. Present findings are consistent with Irvine's (2019) meta-analysis conclusions that positive effect of teaching experience on their effectiveness does not exist: the association of teaching experience with the perception and management of distance education has not been confirmed (although teaching experience of primary school teachers related positively to the number of communication channels and (negatively) to the introducing new topics, the effect size was small). It seems that there are more significant factors related to the methods and quality of teaching than just pure teaching experience.

On the other hand, both emotions and personality factors were related to the perception and management of distance education. In general, positive emotions were associated to more positive perceptions of distance education (higher satisfaction with institutional support, positive feedback, and expectations regarding future changes in teaching style), and negative emotions were associated with more time-consuming management of distance education (more hours spent on distance education and preparation) and negative perception of distance education (less perceived positive feedback, and expectations that teaching style will change just a little after the pandemic period). More importantly, significantly increased negative emotions and decreased positive emotions in our teachers during the pandemic period were observed and these changes were related to the lower subjective satisfaction with their own teaching, lower satisfaction with institutional support, to the amount of time spent on distance education, to more frequent use of 'repeating the topics that were already taught' and less frequent use of 'sending assignments to students, they work alone'. Specifically, in the group of upper-secondary school teachers, anxiety related to the COVID-19 was associated with more frequent 'verbal assessment of students', but perceived risk of COVID-19 was related to the more frequent 'assessment of students using marks'. Previous research showed that emotions were determinants of teachers' burnout risk (Frenzel et al., 2009), emotional exhaustion (Näring 
et al., 2006), well-being (Diener \& Chan, 2011; Näring et al., 2011), and work performance (Frenzel et al., 2009; Yoo \& Carter, 2017), and changes in teachers' emotions-as in present study-might have negative consequences, from the loss of control and negative behavior (Makhwathana et al., 2017) to less effective teaching (Frenzel et al., 2016; Makhwathana et al., 2017 as well as present results).

Present findings further support previous ones that personality is associated with teachers' work engagement, job satisfaction, performance and retention outcomes (Klassen \& Tze, 2014; Kokkinos, 2007; Perera et al., 2018; Rockoff et al., 2011). The trait negative emotionality contributed to reduced satisfaction with institutional support, to perceived negative feedback from parents, students and school leadership team, and lower teaching engagement. Other personality traits were related to the perception and management of distance education rather positively (all related to more positive feedback). Both agreeableness and extraversion were related to more time spent on distance education, agreeableness also to satisfaction with institutional support and extraversion to verifying students' knowledge through oral examination. Consistently conscientiousness was associated with the tendency to check students' task completion. The most associations were revealed in the trait open-mindedness. Open-minded teachers were more satisfied with institutional support, but demanded more of themselves (lower satisfaction with own system of work) which might explain their greater willingness to change the teaching style (there was negative correlation between subjective satisfaction and willingness to change the teaching style, Appendix B), more hours spent on distance education, and preference to implement methods that are not as common (using oral examination rather than tests and repeating the topics that were already taught rather than introducing new topics).

\section{Conclusions and Implications}

Although not all schools in the country participated in the research and all indicators of perception and management of distance education were merely self-reported, the findings sufficiently revealed how teachers worked and what was different in their work during the pandemic period. There are two important findings in our study. The first one is associated with significantly increased negative emotions (and decreased positive emotions) due to school closures. The second finding relates to the relation between teaching emotions, personality and distance education.

Personality and emotions are related to teachers' work engagements, performance, and satisfaction. The assessment of the above-mentioned factors should be a part of pre-service teachers' training. It can be also used as an effective tool that might enable teachers explore their own predispositions and control or regulate their own emotions. Present findings highlight the importance of courses focused on improving social and psychological skills during the university training from self-exploration, self-knowledge, meta-cognitions, through knowing own emotions, coping strategies, and communication styles, to better understanding of the relation between personality and work engagement and effectiveness. These skills should help (both pre-service and in-service) teachers manage difficult situations, similar to the coronavirus pandemic.

The last but even more important finding was that despite of disadvantages related to online education in the pandemic period (e.g. no contact with some students, limited opportunities for motivation and support), the majority of teachers reported willingness for partial changes in their teaching style ( $88.1 \%$ of primary school teachers and $84.5 \%$ of upper-secondary school teachers). It seems that new experience in the pandemic era could lead to a bottom-up change in the education system. The question now is whether teachers will have enough energy and motivation to insist on changes in the education system and whether their requests will be heard. 
Eva BALLOVÁ MIKUŠKOVÁ, Marcela VEREŠOVÁ. Distance education during Covid-19: The perspective of Slovak teachers

PROBLEMS

OF EDUCATION

IN THE $21^{\text {st }}$ CENTURY

Vol. 78, No. 6, 2020

900

\section{References}

Barrick, M. R., \& Mount, M. K. (1993). Autonomy as a moderator of the relationships between the Big Five personality dimensions and job performance. Journal of Applied Psychology, 78(1), 111-118. https://doi.org/10.1037/0021-9010.78.1.111

Burstein, R. (2020). Research Eclipsed: How Educators are reinventing research-informed practice during the pandemic. Research Report.

Cleveland-Innes, M., \& Campbell, P. (2012). Emotional presence, learning, and the online learning environment. International Review of Research in Open and Distance Learning, 13(4), 269-292. https://doi.org/10.19173/irrodl.v13i4.1234

Cypryańska, M., \& Nezlek, J. B. (2020). Anxiety as a mediator of relationships between perceptions of the threat of COVID-19 and coping behaviors during the onset of the pandemic in Poland. Working paper. https://doi.org/10.31219/osf.io/mkxgw

Danaher, P. A., \& Umar, A. (2010). Contemporary research on open and distance learning in teacher education. In Danaher, P.A., Umar, A. (Eds.), Perspectives on distance education: Teacher education through open and distance learning (pp. 7-22). Commonwealth of Learning. https://doi.org/10.1080/02680513.2012.716661

Diener, E., \& Chan, M. Y. (2011). Happy people live longer : Subjective well-being. Applied Psychology: Health and Well-Being, 3(1), 1-43. https://doi.org/10.1111/j.1758-0854.2010.01045.x

Ferguson, K., Mang, K., \& Frost, L. (2017). Teacher stress and social support usage. Brock Education Journal, 26(2), 62-86. https://doi.org/10.26522/brocked.v26i2.606

Fernández-Berrocal, P., Gutiérrez-Cobo, M. J., \& Rodriguez-Corrales, J. (2017). Teachers' affective wellbeing and teaching experience: The protective role of perceived emotional intelligence. Frontiers in Psychology, 8(2227), 1-8. https://doi.org/10.3389/fpsyg.2017.02227

Frenzel, A. C., Goetz, T., Stephens, E., \& Jacob, B. (2009). Antecedents and effects of teachers' emotional experiences: An integrated perspective and empirical test. In P. A. Schutz (Ed.), Advances in teacher emotion research: The impact on teachers'lives (pp. 129-151). Springer.

Frenzel, A. C., Pekrun, R., Goetz, T., Daniels, L. M., Durksen, T. L., Becker-Kurz, B., \& Klassen, R. M. (2016). Measuring teachers' enjoyment, anger, and anxiety: The Teacher Emotions Scales (TES). Contemporary Educational Psychology, 46, 148-163. https://doi.org/10.1016/j. cedpsych.2016.05.003

Göncz, L. (2017). Teacher personality: A review of psychological research and guidelines for a more comprehensive theory in educational psychology. Open Review of Educational Research, 4(1), 75-95. https://doi.org/10.1080/23265507.2017.1339572

Grandey, A. A. (2003). When 'The show must go on': Surface acting as determinants of emotional exhaustion and peer-rated service delivery. Academy of Management Journal, 46(1), 86-96. https://doi.org/10.5465/30040678

Halama, P., Kohút, M., Soto, C. J., \& John, O. P. (2020). Slovak adaptation of the Big Five Inventory (BFI-2): Psychometric properties and initial validation. Studia Psychologica, 62(1), 74-87. https://doi.org/10.31577/sp.2020.01.792

Inter-agency Network for Education in Emergencies. (2020). Technical Note on Education during the COVID-19 Pandemic. New York: INEE.

Irvine, J. (2019). Relationship between teaching experience and teacher effectiveness: Implications for policy decisions. Journal of Instructional Pedagogies, 22, 1-19.

Judge, T. A., Heller, D., \& Mount, M. K. (2002). Five-factor model of personality and job satisfaction: A metaanalysis. Journal of Applied Psychology, 87, 530-541. https://doi.org/10.1037/0021-9010.87.3.530

Kim, L. E., Jörg, V., \& Klassen, R. M. (2019). A meta-analysis of the effects of teacher personality on teacher effectiveness and burnout. Educational Psychology Review, 31, 163-195. https://doi.org/10.1007/s10648-018-9458-2

Klassen, R. M., \& Tze, V. M. C. (2014). Teachers'self-efficacy, personality, and teaching effectiveness: A meta-analysis. Educational Research Review, 12, 5976. https://doi.org/10.1016/j.edurev.2014.06.001

Kokkinos, C. M. (2007). Job stressors, personality, and burnout in primary school teachers. The British Psychological Society, 77, 229-243. https://doi.org/10.1348/000709905X90344

Latchem, C. R., \& Jung, I. (2009). Distance and blended learning in Asia. Routledge. 
Makhwathana, R. M., Mudzielwana, N. P., Mulovhedzi, S. A., \& Mudau, T. J. (2017). Effects of teachers' emotions in teaching and learning in the foundation phase. Journal of Psychology, 8(1), 28-35. https://doi.org/10.1080/09764224.2017.1335677

Näring, G., M. Briët and A. Brouwers. (2006). Beyond demands-control: Emotional labor and symptoms of burnout in teachers. Work \& Stress, 20(4), 303-15. https://doi.org/10.1080/02678370601065182

Näring, G., Vlerick, P., \& van de Ven, B. (2011). Emotion work and emotional exhaustion in teachers: The job and individual perspective. Educational Studies, 38(1), 63-72. https://doi.org/10.1080/03055698.2011.567026

Perera, H. N., Granziera, H., \& McIlveen, P. (2018). Profiles of teacher personality and relations with teacher self-efficacy, work engagement, and job satisfaction. Personality and Individual Differences, 120, 171-178. https://doi.org/10.1016/j.paid.2017.08.034

Podolsky, A., Kini, T., \& Darling-Hammond, L. (2019). Does teaching experience increase teacher effectiveness? A review of US research. Journal of Professional Capital and Community, 4(4), 286-308. https://doi.org/10.1108/JPCC-12-2018-0032

Rockoff, J. E., Jacob, B. A., Kane, T. J., \& Staiger, Douglas, O. (2011). Can you recognize an effective teacher when you recruit one? Education Finance and Policy, 6(1), 43-74. https://doi.org/10.3386/w14485

Shohel, M. M. C. (2012). Open and distance learning for teachers' professional development: The English in Action (EIA) Model for the Global South. In Moore, J. L., \& Benson, A. (Eds.), International perspectives of distance learning in higher education (pp. 93-108). IntechOpen. https://doi.org/10.5772/33117

Shohel, M. M. C., \& Banks, F. (2010). Teachers' professional development through the English in action secondary teaching and learning programme in Bangladesh: Experience from the UCEP schools. Procedia Social and Behavioral Sciences, 2(2), 5483-5494. https://doi.org/10.1016/j.sbspro.2010.03.894

Šrol, J., Ballová Mikušková, E., \& Čavojová, V. (2020). When we are worried, what are we thinking? Anxiety, lack of control, and conspiracy beliefs amidst the COVID-19 pandemic. Working paper. https://doi.org/10.31234/osf.io/f9e6p

Tao, Y., \& Yeh, Ch. R. (2008). Typology of teacher perception toward distance education issues - A study of college information department teachers in Taiwan. Computers \& Education, 50(1), 23-36. https://doi.org/10.1016/j.compedu.2006.03.005

Yoo, J., \& Carter, D. (2017). Teacher emotions and learning as praxis: Professional development that matters. Australian Journal of Teacher Education, 42(3), 38-52. http://dx.doi.org/10.14221/ajte.2017v42n3.3

Watson, D., \& Clark, L. A. (1988). Development and validation of brief measures of positive and negative affect: The PANAS Scales. Journal of Personality and Social Psychology, 54(6), 1063-1070. https://doi.org/10.1037//0022-3514.54.6.1063 
Eva BALLOVÁ MIKUŠKOVÁ, Marcela VEREŠOVÁ. Distance education during Covid-19: The perspective of Slovak teachers

PROBLEMS

OF EDUCATION

IN THE $21^{\text {st }}$ CENTURY Vol. 78, No. 6,2020

902

\section{Appendix A}

Table A

Differences between Primary and Upper-Secondary School Teachers in Perception and Management of Distance Teaching

\begin{tabular}{|c|c|c|c|c|c|c|c|}
\hline & \multicolumn{4}{|l|}{$M(S D)$} & \multicolumn{3}{|c|}{$95 \% \mathrm{Cl}$} \\
\hline & $P$ & U-S & $t$ & $d f$ & $p$ & Lower & upper \\
\hline \multicolumn{8}{|l|}{ Demography } \\
\hline Age & $45.14(9.97)$ & $44.03(11.86)$ & 0.840 & 377 & .401 & -1.49 & 3.72 \\
\hline Experience & $19.56(10.86)$ & $17.10(11.14)$ & 2.238 & 377 & .026 & 0.07 & 1.08 \\
\hline Number of subjects & $3.35(2.06)$ & $2.77(1.86)$ & 1.766 & 377 & .078 & -0.28 & 5.20 \\
\hline \multicolumn{8}{|l|}{ Communication channels } \\
\hline $\mathrm{N}$ of com_channels - before $\mathrm{e}^{\mathrm{i}}$ & $3.00(1.70)$ & $3.69(1.28)$ & -3.334 & 377 & .001 & -1.10 & -0.28 \\
\hline $\mathrm{N}$ of com_channels - during & $4.25(1.50)$ & $4.47(1.35)$ & -1.151 & 377 & .251 & -0.58 & 0.15 \\
\hline Phone & $0.42(0.78)$ & $0.35(0.82)$ & 0.738 & 377 & .461 & -0.12 & 0.27 \\
\hline E-mail & $0.89(1.05)$ & $1.68(1.37)$ & -5.385 & 377 & .000 & -1.06 & -0.49 \\
\hline Edupage & $1.43(1.49)$ & $1.88(1.49)$ & -2.32 & 377 & .021 & -0.81 & -0.07 \\
\hline $\begin{array}{l}\text { Zoom, webex, moodle, jitsi meet, } \\
\text { skype }\end{array}$ & $0.42(0.84)$ & $0.68(1.14)$ & -2.154 & 377 & .032 & -0.48 & -0.02 \\
\hline Microsoft teams, google classroom & $0.34(0.84)$ & $0.41(1.02)$ & -0.667 & 377 & .505 & -0.30 & 0.15 \\
\hline Messenger, facebook & $0.88(1.26)$ & $0.69(1.17)$ & 1.18 & 377 & .239 & -0.12 & 0.50 \\
\hline Whatsapp, Viber, Hangouts & $0.26(0.71)$ & $0.28(0.83)$ & -0.184 & 377 & .854 & -0.20 & 0.17 \\
\hline Others & $0.41(0.90)$ & $0.32(0.81)$ & 0.805 & 377 & .421 & -0.13 & 0.31 \\
\hline \multicolumn{8}{|l|}{ Management of DT } \\
\hline Hours of DT - before & $1.71(2.35)$ & $2.45(2.59)$ & -2.404 & 377 & .017 & -1.34 & -0.13 \\
\hline Hours of DT- during & $4.88(3.43)$ & $6.08(3.66)$ & -2.703 & 377 & .007 & -2.07 & -0.33 \\
\hline Hours of preparation - before & $2.18(1.04)$ & $2.23(1.22)$ & -0.424 & 377 & .672 & -0.33 & 0.21 \\
\hline Hours of preparation - during & $3.01(1.22)$ & $3.12(1.42)$ & -0.684 & 377 & .495 & -0.43 & 0.21 \\
\hline $\begin{array}{l}\text { 1. Sending assignments to students, } \\
\text { they work at home alone }\end{array}$ & $1.70(0.52)$ & $1.81(0.43)$ & -1.704 & 377 & .089 & -0.24 & 0.02 \\
\hline 2. Checking all tasks students send & $1.85(0.41)$ & $1.92(0.27)$ & -1.388 & 377 & .166 & -0.16 & 0.03 \\
\hline $\begin{array}{l}\text { 3. Repeating the topics that were } \\
\text { covered before the pandemic. }\end{array}$ & $1.40(0.64)$ & $1.30(0.65)$ & 1.207 & 377 & .228 & -0.06 & 0.26 \\
\hline 4. Covering new topics & $1.74(0.52)$ & $1.77(0.51)$ & -0.472 & 377 & .637 & -0.16 & 0.10 \\
\hline 5. Verbal assessment of students & $1.79(0.45)$ & $1.34(0.72)$ & 6.864 & 377 & .000 & 0.32 & 0.58 \\
\hline 6. Assessing students by marks & $0.50(0.69)$ & $1.48(0.68)$ & -11.256 & 377 & .000 & -1.16 & -0.81 \\
\hline $\begin{array}{l}\text { 7. Verifying students' knowledge with } \\
\text { an oral answer }\end{array}$ & $0.46(0.70)$ & $0.39(0.69)$ & 0.794 & 377 & .428 & -0.10 & 0.25 \\
\hline $\begin{array}{l}\text { 8. Verifying students' knowledge with } \\
\text { tests }\end{array}$ & $0.63(0.69)$ & $0.86(0.77)$ & -2.495 & 377 & .013 & -0.40 & -0.05 \\
\hline \multicolumn{8}{|l|}{ Perception of DT } \\
\hline Subjective satisfaction & $3.89(0.93)$ & $3.79(0.82)$ & 0.918 & 377 & .359 & -0.12 & 0.34 \\
\hline Satisfaction with instit_support & $3.93(1.27)$ & $4.22(1.19)$ & -1.778 & 377 & .076 & -0.60 & 0.03 \\
\hline Feedback & $4.96(0.74)$ & $4.78(0.65 n ̌$ & 2.001 & 377 & .046 & 0.00 & 0.36 \\
\hline Expectation & $2.42(0.71)$ & $2.40(0.78)$ & 0.195 & 377 & .846 & -0.16 & 0.20 \\
\hline
\end{tabular}

Note: $\mathrm{N}_{\text {primary }}=302 ; \mathrm{N}_{\text {upper-secondary }}=77 ; \mathrm{P}$ - primary school teachers, U-S - upper-secondary school teachers 


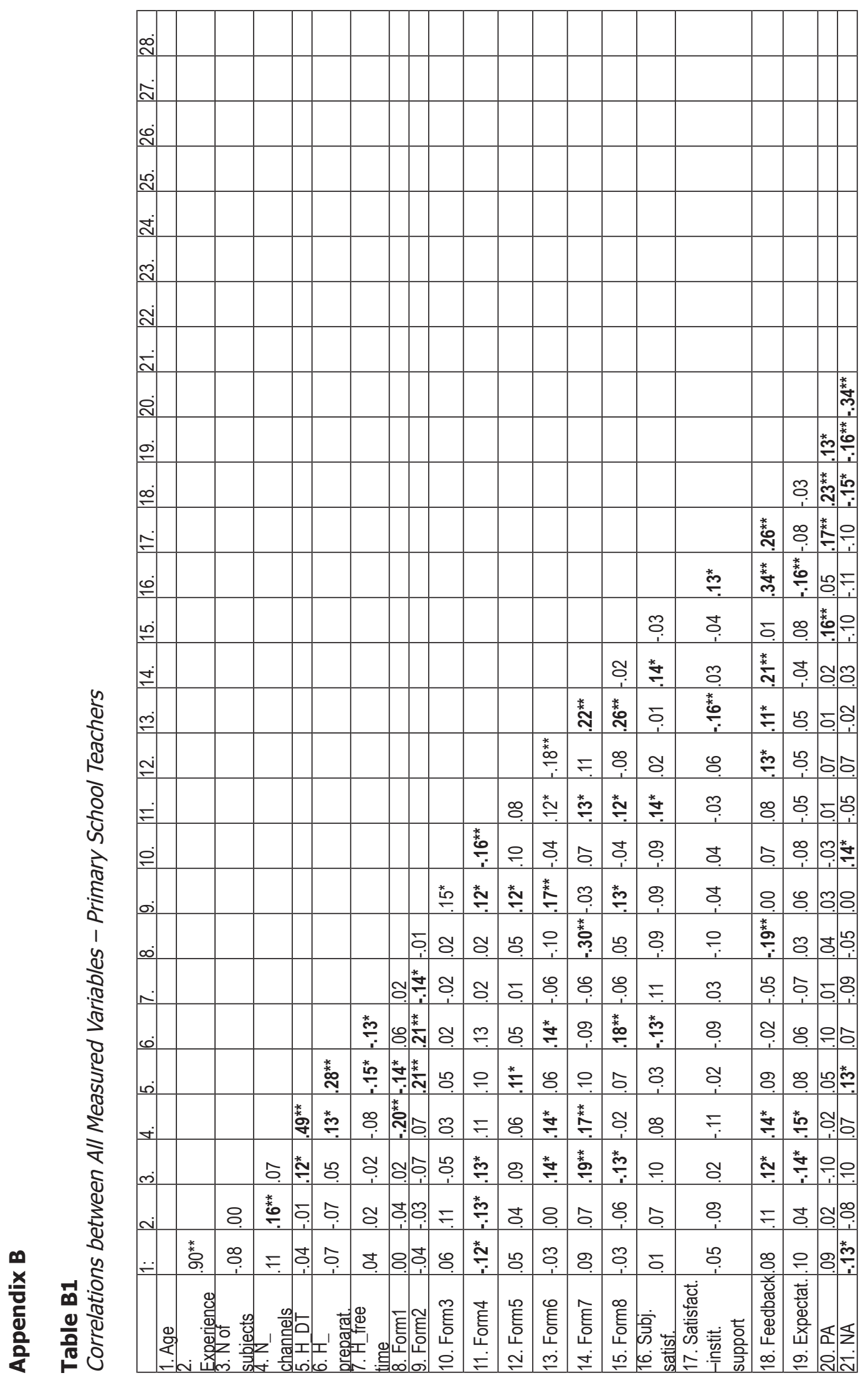


PROBLEMS

OF EDUCATION

IN THE $21^{\text {st }}$ CENTURY

Vol. 78 , No. 6, 2020

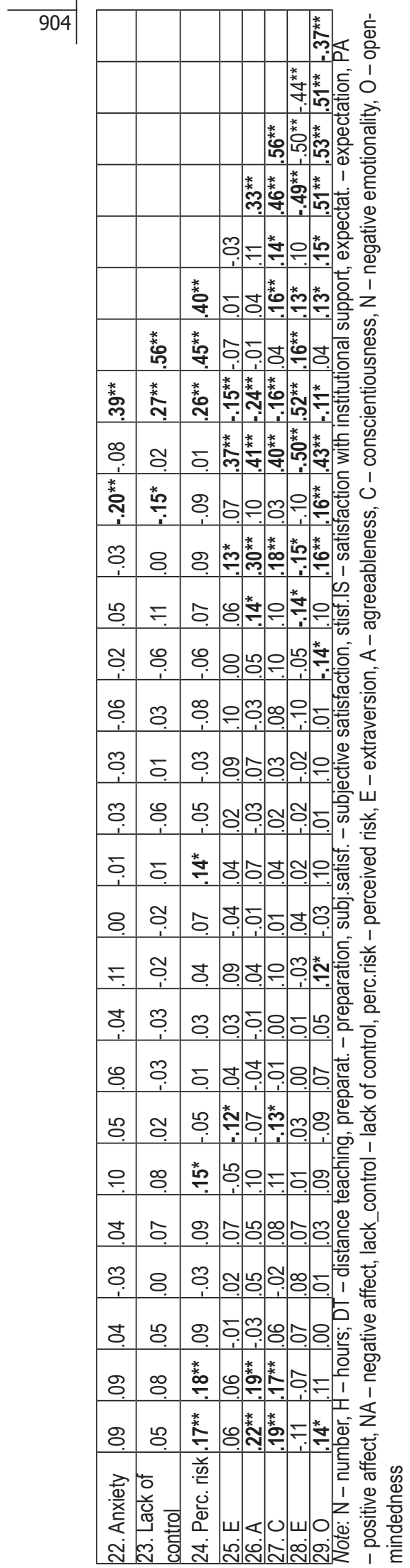

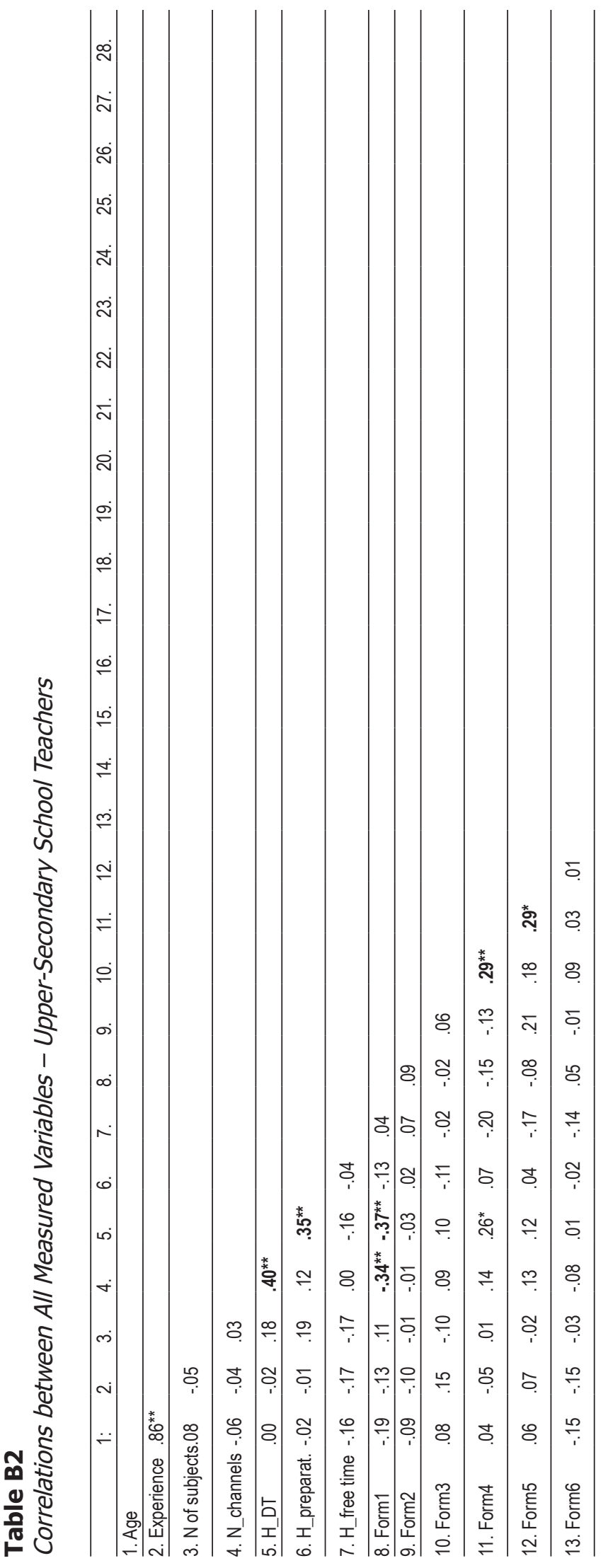


Eva BALLOVÁ MIKUŠKOVÁ, Marcela VEREŠOVÁ. Distance education during Covid-19: The perspective of Slovak teachers

PROBLEMS

OF EDUCATION

IN THE $21^{\text {st }}$ CENTURY

Vol. 78, No. 6, 2020

906
Received: September 08, 2020

Accepted: November 30, 2020

Cite as: Ballova Mikuškova, E., \& Verešova, M. (2020). Distance education during Covid-19: The perspective of Slovak teachers. Problems of Education in the $21^{\text {st }}$ Century, 78(6), 884906. https://doi.org/10.33225/pec/20.78.884

\begin{tabular}{|c|c|}
\hline $\begin{array}{l}\text { Eva Ballová Mikušková } \\
\text { (Corresponding author) }\end{array}$ & $\begin{array}{l}\text { PhD, Assistant Professor, Constantine the Philosopher University in Nitra, Drážovská } \\
\text { 4, } 94101 \text { Nitra, Slovakia. } \\
\text { E-mail: ebmikuskova@ukf.sk } \\
\text { ORCID: https://orcid.org/0000-0002-9162-7735 }\end{array}$ \\
\hline Marcela Verešová & $\begin{array}{l}\text { PhD, Associate Professor, Constantine the Philosopher University in Nitra, } \\
\text { Drážovská 4, } 94101 \text { Nitra, Slovakia. } \\
\text { E-mail: mveresova@ukf.sk } \\
\text { ORCID: https://orcid.org/0000-0003-1858-2996 }\end{array}$ \\
\hline
\end{tabular}

